\title{
Special Section: Social Insects in the Neotropics
}

\author{
FB Noll ${ }^{1}$, fS Nascimento ${ }^{2}$, H Vasconcelos ${ }^{3}$ \\ 'Depto de Zoologia e Botânica, IBILCE-UNESP, São José do Rio Preto, SP, Brasil \\ ${ }^{2}$ Depto de Biologia, FFCLRP-USP, Ribeirão Preto, SP, Brasil \\ ${ }^{3}$ Instituto de Biologia, UFU, Uberlândia, MG, Brasil
}

Published online: 14 November 2018

Ants, termites, wasps, and bees are representatives of a small-but very successful-group of organisms that achieved the highest degree of social organization among animals, known as eusociality. Eusociality is one of the main reasons that explain the ecological dominance of these insects. Although ants, termites, social wasps, and bees represent a tiny fraction of the biodiversity of a tropical forest, their biomass is greater than that of all vertebrate species combined. In addition, they play key ecological roles and provide many services to humankind. Termites have a great ability to digest cellulose and thus are of key importance for soil formation and the cycling of nutrients. Termites are regarded as "ecosystem engineers" since the abiotic and biotic modifications they cause in the habitat influence the abundance of many other species. Wasps and ants are voracious predators of other insects and as such help to regulate the population of these insects, including those that are pests in agriculture. Ants have also evolved mutualistic relationship with many plant species, providing the dispersal of their seeds or, most commonly, protection against herbivores. Bees are the chief pollinators of most flowering plants and many crops and plantations depend heavily on bees to maintain their productivity. Without bees, many of the vegetables we eat every day would simply disappear.

The Neotropical region extends from South America through Central America into tropical Mexico and it is wellknown for the endemicity of several taxa of animals and plants. Neotropical social insects constitute a very diverse group of insects, with enormous ecological dominance. A traditional example shows that in some Neotropical forests, social insects constitute approximately $30 \%$ of animal biomass (ants and termites) and $80 \%$ of total insect biomass (Fittkau \& Klinge 1973). In terms of diversity, the Neotropics are the second most diverse in terms of described termite species; $30 \%$ of ant species are found in the Neotropics (the

richest region in the world); $70 \%$ of the species of Neotropical social wasps (mostly Polistinae) are endemic; $60 \%$ of social bees (Apinae) are also endemic to the Neotropics, if we include orchid bees, that may bear some pre-social behaviors. These data show that social insects are essential for the survival of the Neotropical region.

The most important threats to social insects are the loss of their diversity in response to anthropogenic activities. Reasons implicating in species decline include mainly the habitat loss due to landscape fragmentation, pesticides, invasive species, and, ultimately, the global climate change. The understanding of the important role of social insects in the ecosystem and economy urges through efforts from basic to applied research together with biodiversity conservation.

This Special Section is dedicated to this exquisite group of the world biodiversity. A set of the articles on Neotropical social Hymenoptera accepted for publication in Neotropical Entomology in the end of 2017 and in 2018 were grouped in this issue. Seven articles are focused on the ecological functions and population regulation of ants (Achury \& Suarez 2017, Grüter et al 2018, Knowlton \& Kamath 2018, Rocha et al 2018a, b, Sheeja et al 2018, Walter et al 2018); three articles are dedicated to the ecology and diversity of bees (Campollo-Ovalle \& Sánchez 2018, Poveda-Coronel et al 2018, Saravia-Nava et al 2018) and other two articles explore the ecology of termites (Ferreira et al 2018, Rodrigues et al 2018). By publishing them together, we aim to bring light to the diversity, species interactions, population regulation, and the highly relevant ecological roles of these insects in tropical ecosystems.

\section{References}

Achury R, Suarez AV (2017) Richness and composition of grounddwelling ants in tropical rainforest and surrounding landscapes in the Colombian inter-Andean valley. Neotrop Entomol https://doi. org/10.1007/s13744-017-0565-4

Campollo-Ovalle A, Sánchez D (2018) Temporal response of foragers and guards of two stingless bee species to cephalic compounds of the 
robber bee Lestrimelitta niitkib (Ayala) (Hymenoptera, apidae). Neotrop Entomol https://doi.org/10.1007/s13744-018-0599-2

Ferreira DV, Sacramento JJM, Rocha MLC, Cruz JS, Santana DL, Cristaldo PF, Araújo APA (2018) Does distance among colonies and resource availability explain the intercolonial agrassiveness in Nasutitermes aff. Coxipoensis? Neotrop Entomol https://doi.org/10.1007/s13744-0180625-4

Fittkau EJ, Klinge H (1973) On biomass and trophic structure of the central Amazonian rain forest ecosystem. Biotropica 5:2-14

Grüter C, Wüst M, Cipriano AP, Nascimento FS (2018) Tandem recruitment and foraging in the pionering ant Pachycondyla harpax (Fabricius). Neotrop Entomol https://doi.org/10.1007/s13744-0170571-6

Knowlton ED, Kamath A (2018) Ants do not traverse the silk of adult female Nephila clavipres (Linnaeus) webs. Neotrop Entomol https:// doi.org/10.1007/s13744-018-0631-6

Poveda-Coronel CA, Riaño-Jiménez D, Cure JR (2018) Diversity and phenology of wild bees in a highly disturbed tropical dry forest "Desierto de la Tatacoa", Huila-Colombia. Neotrop Entomol https://doi.org/10. 1007/s13744-017-0578-z

Rocha MLC, Cristaldo PF, Cruz JS, Sacramento JJM, Ferreira DV, Araújo APA (2018a) Ants associated with Turnera subulata (Turneraceae): elaiosome attraction, seed dispersion and germination. Neotrop Entomol https://doi.org/10.1007/s13744-018-0616-5

Rocha G, BMS O, Melo CR, Sampaio TS, Blank AF, Lima AD, Nunes RS, APA A, Cristaldo PF, Bacci L (2018b) Lethal effect and behavioral responses of leaf-cutting ants to essential oil of Pagostemon cablin(Lamiaceae) and its nanoformulation. Neotrop Entomol https://doi.org/10.1007/s13744-018-0615-6

Rodrigues VB, Costa DA, Cristaldo PF, DeSouza O (2018) Lagged population growth in a termite host colony: cause or consequence of inquilinism? Neotrop Entomol https://doi.org/10.1007/s13744-0180634-3

Saravia-Nava A, Niemeyer HM, Pinto CF (2018) Pollen types used by the native stingless bee, Tetragonisca angustula (Latreille) in an AmazonChiquitano transitional forest of Bolivia. Neotrop Entomol https://doi. org/10.1007/s13744-018-0612-9

Sheeja CC, Thushara VV, Divya L (2018) Caste-specific expression of $\mathrm{Na}^{+} /$ $\mathrm{K}^{+}-$ATPase in the Asian weaver ant, Oecophylla smaragdina (Fabricius, 1975). Neotrop Entomol https://doi.org/10.1007/s13744018-0598-3

Walter B, Graclik A, Tryjanowski P, Wasielewski O (2018) Ants response to human-induced disturbance in a rain tropical forest. Neotrop Entomol https://doi.org/10.1007/s13744-018-0624-5x 